DOI: doi.org/10.21272/shaj.2018.i31.p.69

OLEKSANDR B.SUPRUNENKO

$\mathrm{PhD}$ (History), Vasyl Krychevsky Poltava Local Lore Museum (Ukraine)

\title{
REVIEW OF THE MONOGRAPH: SKYRDA I.M. THE XII ARCHAEOLOGICAI CONGRESS: PRECONDITIONS, A COURSE OF EVENTS, THE HISTORICAL VALUE. KHARKIV, 2018. 252 p.
}

СУПРУНЕНКО О.Б.

Кандидат історичних наук, Полтавський краєзнавчий музей імені Василя Кричевського (Україна)

РЕЦЕНЗІЯ НА МОНОГРАФІЮ: СКИРДА І.М. ХІІ АРХЕОЛОГІЧНИЙ З’ЇЗД: ПЕРЕДУМОВИ, ПЕРЕБІГ ПОДІЙ, ІСТОРИЧНЕ ЗНАЧЕННЯ. ХАРКІВ: ХНУ IMEНI В.Н. КАРАЗІНА, 2018. 252 C.

СУПРУНЕНКО А.Б.

Кандидат исторических наук, Полтавский краеведческий музей имени Василия Кричевского (Украина)

\section{РЕЦЕНЗИЯ НА МОНОГРАФИЮ: СКИРДА И.Н. ХІІ АРХЕОЛОГИЧЕСКИЙ СЬЕЗД: ПРЕДПОСЫЛКИ, ХОД СОБЫТИЙ, ИСТОРИЧЕСКОЕ ЗНАЧЕНИЕ. ХАРЬКОВ, 2018. 252 С.}

В останні десятиліття історія археології отримала впевнений розвиток і позиціонує себе як самостійна субдисципліна. Хоча при цьому чимало проблем, пов'язаних, наприклад, із діяльністю та роллю археологічних з'їздів на теренах сучасної України ще залишалася не висвітленими в повному обсязі. Цю лакуну відносно такого визначного явища, як ХІІ Археологічний з'їзд, що відбувся у Харкові в 1902 р., заповнює монографічне дослідження I.М. Скирди.

Інтерес сучасних дослідників до історії науки, зокрема й до історії археології, робить це монографічне дослідження доволі актуальним. Робота становить значний науковий інтерес і у зв'язку з її історіографічним підходом до вивчення цієї проблеми. Зокрема, викликає інтерес те, що історія Харківського археологічного форуму розглядається в контексті формування фахового наукового співтовариства, становлення каналів наукової комунікації, розвитку інтелектуальної історії, а це, в свою чергу, дає можливість зрозуміти процеси дисциплінізації й інституалізації історичної та археологічної наук.

Аналізуючи монографію, в першу чергу, слід відзначити чітко окреслену мету і завдання дослідження, напрямки наукового пошуку та введення до наукового обігу значних обсягів опублікованих і неопублікованих джерел з архівних та музейних колекцій, що дало змогу авторці сформулювати головні положення й структурно подати основні матеріали та навести лаконічні висновки.

Варто відзначити обрану теоретико-методологічну основу, продуману структуру роботи, підпорядковану саме меті дослідження, чітко визначені розділи й підрозділи, що сприяло науковому підходу до висвітлення проблеми і підготовки у підсумку обгрунтованих узагальнень, висновків, котрі збагачують знання про об'єкт дослідження.

Ретельний і виважений аналіз на основі використання загальнонаукових, конкретнонаукових та спеціально-історичних методів досліджень сприяв предметності розкриття теми. Авторкою визначена ступінь розробки теми в історичній літературі, окреслена низка дискусійних проблем, що мають перспективи подальшого вивчення. 
I.M. Скирда детально й глибоко проаналізувала історію проведення у Харкові XII Археологічного з'їзду 1902 р., відтворила цілісну картину його підготовки та проведення. Були виокремлені завдання, основні напрями та результати роботи Московського i Харківського попередніх комітетів. Авторка коректно оцінила внесок регіональних комісій та відділень у підготовку з'їзду.

Головну увагу в монографії зосереджено на аналізі кола наукових інтересів учасників Харківського з'їзду, зокрема, проблем, що формували предметні поля різних дисциплін історичного профілю: археології, нумізматики, історії, краєзнавства, етнографії, архівознавства. Тому за діапазоном проблематики досліджень цей з'їзд перевершив здобутки інших археологічних форумів. Аналіз мовного питання, позиція галицьких учених, які вели боротьбу за право використовувати українську мову в науці, стали предметом окремого аналізу.

Значна частина праці присвячена аналізу роботи секцій етнографічного, краєзнавчого, мистецтвознавчого спрямування, що дозволило зробити справедливий висновок про українознавчий характер XII Археологічного з'їзду. Також у дослідженні наголошується на ролі Харківського археологічного форуму у виявленні й дослідженні писемних пам'яток, що відображають історію та культуру України, оскільки до наукового обігу було введено чималий масив історичних джерел з історії Гетьманщини та Слобідської України тощо.

XII Археологічний з'їзд відіграв важливе суспільне значення в контексті процесів формування національної ідентичності. Тож у результаті вивчення широкого кола джерел дослідниця дійшла висновку, що з'їзд став одним із найвизначніших наукових форумів в Україні початку XX ст. і суттєво вплинув на розвиток гуманітарних наук в українських землях, а інтелектуальна комунікація в галузі археології й історії спричинила взаємопроникнення та запозичення різних елементів “наукової культури” того часу, котрі впливали на внутрішній розвиток цих наук, громадську позицію вчених як інтелектуалів і визначали їх статус в академічному співтоваристві. Монографія має й виразну практичну цінність, особливо для дослідження інтелектуального простору України початку XX ст. та розвитку у цей час краєзнавчих студій.

Підводячи підсумки, слід зазначити, що висновки, зроблені в монографії І.М.Скирди, є оригінальними і вкрай необхідними для розбудови української історіографії. Це дослідження стало продовженням кращих традицій харківської історичної школи і цілком відповідає критеріям її науковості.

Отримано 5.11.2018 